\title{
Platelet Transfusions in Neonates - Unresolved Aspects and Future Directions
}

Thangaraj Abiramalatha ${ }^{1}$, Viraraghavan Ramaswamy ${ }^{2}$, and Sivam Thanigainathan ${ }^{3}$

${ }^{1}$ Kovai Medical Center and Hospital

${ }^{2}$ Ankura Hospital

${ }^{3}$ All India Institute of Medical Sciences - Jodhpur

December 9, 2021

\section{Hosted file}

Main document.docx available at https://authorea.com/users/450475/articles/548766-platelettransfusions-in-neonates-unresolved-aspects-and-future-directions 